\title{
TECHNOLOGICAL ASPECTS OF OBTAINING LIQUID EXTRACTS OF BLACK POPLAR BUDS AND DETERMINING THE STRATEGY FOR THEIR STANDARDIZATION AT THE PHARMACEUTICAL DEVELOPMENT STAGE
}

\author{
A. Bondar, S. Gubar, N. Smielova, T. Shyteyeva, O. Tkachenko, L. Kryvoruchko, K. Karpenko, \\ V. Georgiyants
}

\begin{abstract}
Мета. Проведення досліджень з розробки технології одержання рідких екстрактів тополі чорної бруньок, їх стандартизації та визначення оптимальних параметрів технологічного процесу екстракції, які мають забезпечити необхідний вміст біологічно активних речовин та фармакологічну активність преnapamy.

Методи. Виготовлення рідких екстрактів проводили методом перколяиії. Кількісне визначення суми похідних гідроксикоричної кислоти здійснювали за уніфікованою спектрофотометричною методикою, рекомендованою Державною фармакопеєю України, у перерахунку на кофейну кислоту, за аналітичної

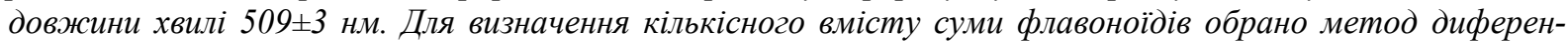
иіальної спектрофотометрії, у перерахунку на лютеолін, за реакцією флавоноїдів з 2 \% розчином алюмінію хлориду у етанолі (96\%) Р за аналітичної довжини хвилі $398 \pm 3$ нм.

Результати. Проведено дослідження з розробки технології одержання рідких екстрактів тополі чорної бруньок. Визначено технологічні параметри подрібненої лікарської рослинної сировини тополі чорної бруньки (насипна маса, коефіцієнт наповнення сухої сировини) та проведено розрахунок параметрів екстракиії. Встановлено, щзо для технологічного процесу необхідно використання 2-го, або 2-го та 3-го зливів, та повернення їх до процесу на першу стадію процесу для серії, яка слідує далі. Для збільшення абсолютного вмісту біологічно активних речовин раціонально змінювати режими екстракції (час настоювання, швидкість витікання екстрагенту, температуру). Проведено кількісне визначення екстрактивних речовин та спектрофотометричне визначення суми похідних гідроксикоричної кислоти у перерахунку на кофейну кислоту, а також суми флавоноїдів у перерахунку на лютеолін на всіх етапах технологічного процесу отримання рідких екстрактів. Встановлено вплив конщентрації екстрагенту на якісний склад отриманого екстракту. Підібрано оптимальні умови екстрагування та розроблено технологію отримання етанольних екстрактів на основі етанолу (96\%) Р та етанолу (70 \%) Р з лікарської рослинної сировини тополі чорної бруньок. Для збільшення абсолютного вмісту біологічно активних речовин у рідких екстрактах експериментально аргументовано збільшення часу настоювання до 24 годин. Проведено напрацювання рідких екстрактів тополі чорної бруньок для їх подальших скринінгових досліджень.
\end{abstract}

Висновки. В результаті проведених досліджень розроблена технологія одержання рідких екстрактів тополі чорної бруньок, проведена їх стандартизація, визначено оптимальні параметри технологічного процесу екстракиї, проведено напрацювання етанольних екстрактів для їх подальших скринінгових досліджень

Ключові слова: екстракція, технологічний процес, рідкий екстракт тополі чорної бруньок, стандартизаиія, спектрофотометрія

Copyright (C) 2020, A. Bondar, S. Gubar, N. Smielova, T. Shyteyeva, O. Tkachenko, L. Kryvoruchko, K. Karpenko, V. Georgiyants. This is an open access article under the CC BY license (http://creativecommons.org/licenses/by/4.0).

\section{Introduction}

Along with the rapid development of the pharmaceutical market for synthetic medicines (drugs), the demand for herbal drugs, which due to high efficiency, low risk of side effects and economic availability, make up a significant part of the therapeutic agents used in modern medicine and pharmacy $[1,2]$.

A promising source of natural biological active substances (BAS) for the creation of new drugs is the medicinal plant raw material (MPRM) of the black poplar (Populus nigra L., family - Salicaceae), which has long been used in both folk and official medicine. The dominant classes of compounds that determine the pharmacological activity of the black poplar buds are hydroxycinnamic acids and their esters, flavonoids and other phenolic compounds (salicylate glycosides, gallic acid derivatives), essential oil [1, 3]. Many scientific studies have found that the majority of black poplar buds flavonoids are of an aglycone nature and have no substituents in the lateral benzene ring, which is why they are peculiar. MPRM also contains organic acids, waxes, vitamin $\mathrm{C}$, resins, fatty oils, etc. [1, 3]. 
Anti-inflammatory, anti-allergic, diuretic, antimicrobial, antiseptic and analgesic effects of black poplar buds have been scientifically confirmed. When applied externally, ointment, tincture and decoction of the raw material have anti-inflammatory, antimicrobial, mild anaesthetic effects in rheumatic joint and muscle pain. Topically, drugs based on black poplar buds are shown for the treatment and prevention of periodontal disease. Internally, the infusion and decoction of the black poplar MPRM are used for diseases of the urinary tract [3-5].

Therefore, increasing the number of domestic plant-based drugs in the pharmaceutical market by expanding the range of dosage forms is one of the important problems of modern pharmaceutical technology [6].

According to scientific literature, it is established that the antimicrobial activity of drugs based on the black poplar buds is mainly due to flavonoids. For example, flavanone pinocembrin exhibits pronounced activity against gram-positive bacteria, and its 7-methoxyderivative - pinostrobine - has a weaker but selective antimicrobial activity against $E$. coli due to the lipophilic properties of the substance and its affinity with the lipid membrane bacterium. The dominant components of poplar buds extracts include hydroxycinnamic acid derivatives having a similar spectrum of pharmacological activity [7].

A study of the antibacterial activity of black poplar bud extracts [8] revealed that the greatest inhibition of the growth zones of gram-positive bacteria E. coli, $S$. aureus and B. subtilis is achieved using ethanol extract (1 $\mathrm{mg} / \mathrm{ml}$ ) (range 12 to $17 \mathrm{~mm}$ ) and pronounced antifungal activity against $A$. niger and $F$. polyferatum (range from 06 to $09 \mathrm{~mm}$ ) [8]. Caffeic acid and flavanol halangin have been identified in Populus nigra L. as active BAS against $A$. fischeri [9].

The antioxidant activity of black poplar buds BAS has been confirmed by numerous studies [10, 11, 12], which in turn may be related to the content of phenolic compounds $[13,14]$, mainly coffee acid and p-coumaric [15-17].

Therefore, it can be concluded that the biological activity of the black poplar buds liquid extract is associated with a large number of compounds, many of which may be unknown, and their concentrations (both absolute and relative) can vary widely.

The standardization of such drugs is advisable to carry out by determining the conditional concentrations of a group of characteristic substances by spectrophotometry.

Therefore, for the quantitative evaluation of the quality of raw materials, methods have been selected that allow evaluating the content of the main BAS of liquid extract of black poplar buds. According to the literature, such substances are a group of compounds of flavonoid series and a group of phenylpropanoid compounds derivatives of hydroxycinnamic acid.

Therefore, the aim of our work was to conduct research on the development of technology for the production of liquid extracts of black poplar buds, their stand- ardization and determine the optimal parameters of the extraction process, which should provide the necessary content of the BAS and the pharmacological activity of the drug.

\section{Planning (methodology) of the research}

To achieve the aim it was necessary to solve the following problems:

- taking into account the results of previous studies on the choice of the optimal extractant of active substances from the raw material of black poplar, to determine the technological parameters of crushed MPRM, to choose and justify the method of extraction;

- to develop optimal extraction modes;

- to develop a model of the technological process of extraction on the basis of the analysis of experimental data of quantitative determination of extractive compounds, sum of flavonoids and sum of derivatives of hydroxycinnamic acids.

\section{Materials and methods}

Liquid extracts obtained by the method of percolation from the MPRM of black poplar buds of the production of TOV "Sumyfitofarmatsiya" (production series 2,3 ) were used as objects of study in the present work.

The quantitative content of extractives in raw materials was determined by the pharmacopoeial method [18].

For the quantitative determination of the BAS liquid extract of the black poplar buds, the determination of the sum of hydroxycinnamic acid derivatives by the unified spectrophotometric method recommended by the State Pharmacopoeia of Ukraine (SPhU), in terms of coffee acid [18]. The analysis was performed by the standard wavelength method of $509 \pm 3 \mathrm{~nm}$.

To determine the quantitative content of flavonoids, the method of differential spectrophotometry was chosen, which is recommended by the SPhU to determine the amount of flavonoids. Analysis of the quantitative content of the sum of flavonoids was performed by the standard method in terms of luteolin by the reaction of flavonoids with a $2 \%$ solution of aluminium chloride in ethanol (96\%) $R$ at an analytical wavelength of $398 \pm 3 \mathrm{~nm}[18]$.

\section{Research results}

According to the requirements of $\mathrm{SPhU}$, in the manufacture of liquid extracts (in the ratio of 1:1) from one part of the raw material, one part of the extract is obtained, provided that the active substances are extracted from the raw material in the same proportions [14].

From the results of previous studies, ethanol (96\%) $R$ and ethanol (70\%) $R$ were selected as optimal extractants [19].

For the production series of black poplar buds MPRM (series 2, 3), its technological parameters were determined, namely bulk weight and dry material filling ratio of $1 \mathrm{~mm}$ in ethanol (96\%) $R$ and ethanol (70\%) $R$. The results are given in the Table 1. 
Technological parameters of crushed raw material of black poplar buds (1 mm)

\begin{tabular}{|c|c|c|c|}
\hline \multirow{2}{*}{ No. of the production series } & \multirow{2}{*}{ Bulk mass, $\mathrm{g} / \mathrm{cm}^{3}$} & \multicolumn{2}{|c|}{ Dry raw material filling ratio, $\mathrm{cm}^{3} / \mathrm{g}$} \\
\cline { 3 - 4 } & & Ethanol $(96 \%) R$ & Ethanol $(70 \%) R$ \\
\hline 2 & 0.50 & 1.35 & 1.61 \\
\hline 3 & 0.45 & 1.30 & 1.62 \\
\hline
\end{tabular}

It is known from the scientific literature that liquid extracts are obtained by maceration in various modifications, percolation, repercolation, dissolution of thick and dry extracts, etc. To obtain liquid extracts of black poplar buds we have chosen the method of percolation, which consists in extracting the BAS from plant raw materials by washing it with a slow and continuous flow of the extractant. Unlike the maceration method, the percolation method allows to increase the yield of the active substances from the raw material, since the maximum difference of concentrations is created due to the gradual displacement of the extraction with a pure solvent [20].

The extraction procedure of the BAS was performed as follows: the crushed MPRM was enclosed in a percolator and tamped to prevent voids; two layers of gauze and cargo were placed on top of the raw material; under the extractor was installed a glass receiver, opened the bottom tap and poured into the percolator extractant; when the extractant began to leak out of the tap, it was closed, the leaking fluid was returned to the percolator, the tap was closed and the extractant was added "to the mirror" (a small layer of extractant over the raw material); the loaded percolator was left for infusion at room temperature.

The volume of extractant required for introduction to the extractor "to the mirror", the total volume of extractant required for the extraction process and the percolation rate were calculated according to conventional formulas [21], given that the flow rate in 1 hour should be $1 / 12$ parts of the working volume of the percolator. The calculated extraction parameters are given in Table 2.

Table 2

Extraction parameters for testing

\begin{tabular}{|c|c|c|c|c|c|}
\hline Extractant & $\begin{array}{c}\text { Weight of } \\
\text { MPRM, } \\
\mathrm{kg}\end{array}$ & $\begin{array}{c}\text { Volume } \\
\text { of ex- } \\
\text { tract, } 1\end{array}$ & $\begin{array}{c}\text { Raw material } \\
\text { filling ratio }\end{array}$ & $\begin{array}{c}\text { The volume of extract- } \\
\text { ant required to be added } \\
\text { to the extractor "to the } \\
\text { mirror", } 1\end{array}$ & $\begin{array}{c}\text { Percolation rate, (percola- } \\
\text { tor volume 75 ml) }\end{array}$ \\
\hline Ethanol $(96 \%) R$ & 0.025 & 0.025 & 1.3 & 0.030 & $0.1 \mathrm{ml} / \mathrm{min}$ \\
\hline Ethanol $(70 \%) R$ & 0.025 & 0.025 & 1.6 & 0.040 & $0.1 \mathrm{ml} / \mathrm{min}$ \\
\hline
\end{tabular}

The multiplicity of the extraction process was determined according to the developed laboratory technological model. In the extraction tank was placed $25 \mathrm{~g}$ of crushed MPRM of black poplar buds, slowly filled with extractant with open tap (ethanol $(96 \%) R$ or ethanol $(70 \%) R$ ) until the appearance of the "first drop", and then closed the tap. On top of the raw material soaked up "to the mirror", the filter was laid out. The extractant was added until a "mirror" appeared above the top filter. Infusion time -12 hours.

After that, $25 \mathrm{ml}$ of the extractant was slowly added to the extractor and the bottom tap was opened. The discharge rate of the extractant was adjusted by the lower tap. It should be $0.1 \mathrm{ml} / \mathrm{min}$ or enough to discharge $25 \mathrm{ml}$ of the extract in 4-5 hours (1st discharge).

After receiving $25 \mathrm{ml}$ of the extract, the bottom tap was closed and the raw material was left with the extractant "up to the mirror" for another 12 hours. After that, $50 \mathrm{ml}$ of the extractant was slowly added to the extractor, the bottom tap was opened. The discharge rate of the extractant was adjusted by the lower tap. It should be such that it drains $50 \mathrm{ml}$ of the extract in 5-6 hours. Selected the first $25 \mathrm{ml}$ of the extract - the 2nd discharge, the second $25 \mathrm{ml}$ of the extract - the 3rd discharge. In addition, the 4th discharge was made, $25 \mathrm{ml}$ more extractant was added to the extractor and the bottom tap was opened.

The discharge rate of the extractant should be $0.1 \mathrm{ml} / \mathrm{min}$ (4th discharge).

For the four ethanol extracts obtained using ethanol $(70 \%) R$ and the four ethanol extracts extracted from ethanol $(96 \%) R$, the content of extracts and BAS characteristic of the black poplar bud MPRM were determined (Table 3).

The histograms of the study of the results of bud extraction with ethanol (96\%) $R$ and ethanol (70\%) $R$ by the content of extractives and the amount of BAS in ethanol extracts are shown in Fig. 1-3.

Table 3

The amount of extractives and main BAS in $96 \%$ and $70 \%$ ethanol extracts of black poplar bud

\begin{tabular}{|l|c|c|c|c|c|c|c|c|}
\hline \multirow{2}{*}{$\begin{array}{l}\text { Indicator of the sum of substances, relative to their } \\
\text { total content in raw materials }\end{array}$} & \multicolumn{3}{|c|}{ Extractant ethanol (70 \%) $R$} & \multicolumn{5}{|c|}{ Extractant ethanol (96\%) $R$} \\
\cline { 2 - 8 } & \multicolumn{3}{|c|}{ extract № } \\
\hline the amount of extractives, \% & 50.40 & 68.50 & 72.40 & 74.22 & 49.10 & 61.00 & 66.70 & 68.76 \\
\hline the amount of flavonoids, in terms of luteolin, \% & 26.10 & 30.40 & 32.20 & 32.80 & 45.70 & 51.30 & 52.60 & 53.00 \\
\hline $\begin{array}{l}\text { the sum of hydroxycinnamic acids, in terms of cof- } \\
\text { fee acid, \% }\end{array}$ & 51.28 & 69.62 & 73.59 & 75.51 & 47.40 & 56.70 & 59.90 & 61.20 \\
\hline
\end{tabular}




\section{Extractive substances, the percentage of the total} extraction in extract

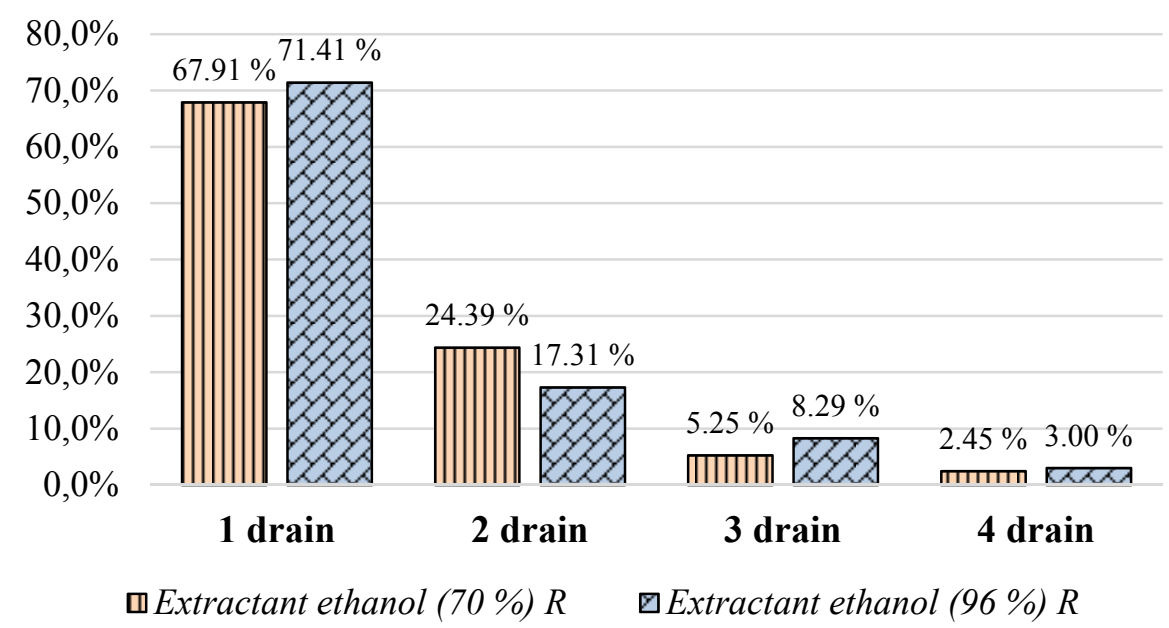

Fig. 1. Dynamics of extraction of extractives in each discharge of the extractant from the total extract based on ethanol (96\%) R and ethanol (70\%) $R$

Hydroxycinnamic acid derivatives (in terms of coffee acid), the percentage of the total extraction in extract

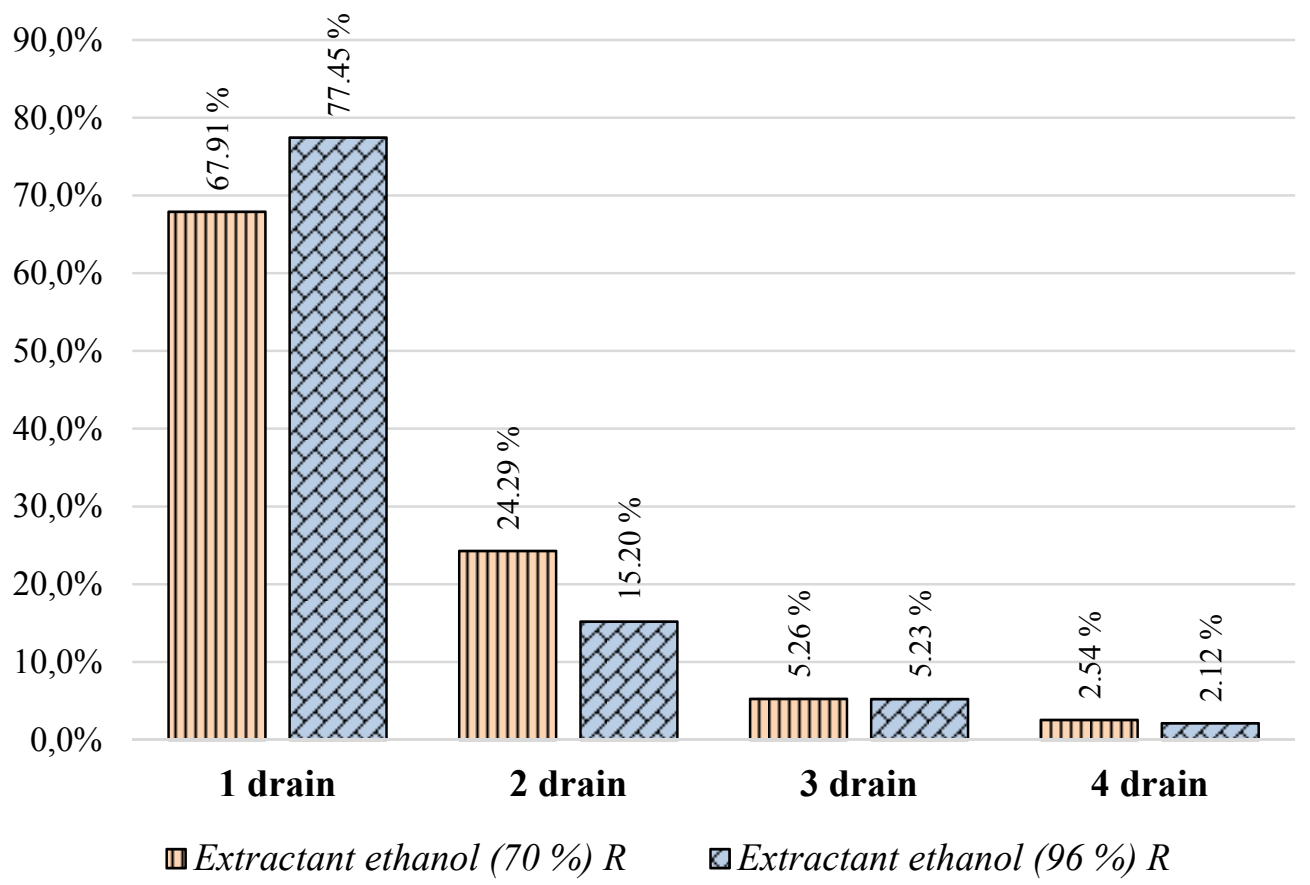

Fig. 2. Dynamics of extraction of the amount of hydroxycinnamic acids, in terms of coffee acid, in each discharge of the extractant from the total extract based on ethanol (96\%) $R$ and ethanol $(70 \%) R$ 


\section{Amount of flavonoids (in terms of luteolin), the percentage of the total extraction in extract}

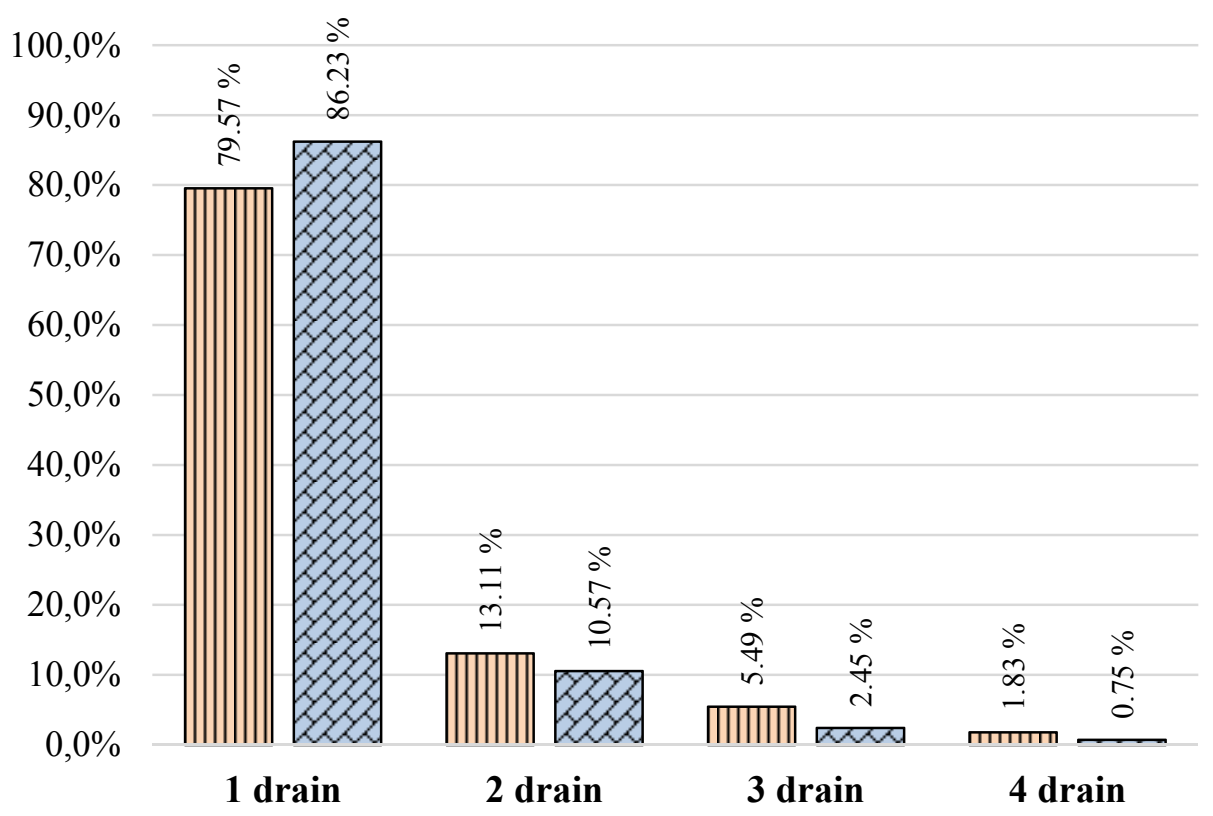

由 Extractant ethanol $(70 \%) R \quad \square$ Extractant ethanol $(96 \%) R$

Fig. 3. Dynamics of extraction of the sum of flavonoids, in terms of luteolin, in each discharge of the extractant from the total extract based on ethanol (96\%) $R$ and ethanol (70\%) $R$

\section{Discussion of research results}

According to the results of studies it is established (tab. 3) that the total amount of extractives calculated in liquid extract with the use of ethanol extractant $(70 \%) \mathrm{R}$ is $74.22 \%$, which, in turn, is more than $5 \%$ the percentage of the amount of extractives contained in the liquid extract using an ethanol extractant (96\%) R (68.76\%). Similar results were obtained when calculating the amount of hydroxycinnamic acid derivatives, calculated on coffee acid, where the content of BAS in liquid extract using an ethanol extractant $(70 \%) \mathrm{R}$ exceeds the content of active substances in the extract using ethanol $(96 \%) R$ by more than $14 \%$. However, the amount of flavonoids in liquid extract obtained using ethanol (96\%) $R$ is almost $10 \%$ higher than the value in liquid extract obtained using ethanol extractant (70\%) R.

In view of the dynamics of the extraction of the substances shown in Fig. 1-3, it can be concluded that about $70-80 \%$ of substances go into the first discharge of the extract, from 10 to $25 \%$ of the substances into the second discharge of the extract, and about $5 \%$ in the third. These data indicate that the process requires the use of the 2 nd or $3 \mathrm{rd}$ discharges and return them to the first stage of the process for the series that follows. In order to increase the absolute content of BAS, it is rational to change the extraction regimes (infusion time, extractant flow rate, temperature), not just the amount of extractant discharge.

Based on the obtained results, the process optimization was carried out. To increase the absolute content of the BAS, the infusion time of the first extract was changed to 24 hours. According to the results of the study it is shown that with increasing the infusion time, the value of the amount of flavonoids and the amount of hydroxycinnamic acids that have passed into the extract, relative to their total content in the raw material, became more in accordance with the ratio of these indicators obtained for the extractant at 12 hour infusion. This pattern holds for both an ethanol-based extract $(96 \%)$ and an ethanol-based extract (70\%) (Fig. 4).

As a result of the conducted researches the strategy for standardization of liquid extract of black poplar buds by two methods of quantitative determination of the content of active substances - the sum of flavonoids and the sum of derivatives of hydroxycinnamic acids was determined.

Limitations of the study. To determine the quantitative content of flavonoids, two differential spectrophotometry techniques were considered, based on the reaction of flavonoids with aluminium chloride or boric acid. These methods are recommended by the SPhU to determine the amount of flavonoids. The presence of hydroxyl groups in the flavonoid compounds influence the absorption maxima depending on their positions. When using various reagents that have an effect on the chromophore system of flavonoids (boric acid, aluminium chloride and others), a bathochromic or hypsochromic shift of the basic absorption maxima is observed and enhances them. Depending on which compounds are presented, the analytical wavelengths may be different.

Flavonoids interact with boric acid in the presence of citric acid (Wilson's reagent) to form yellow-coloured solutions with red fluorescence. When using oxalic acid instead of citric (Taubeck reagent), yellow-green fluorescence is formed. Literary references indicate that both 5hydroxyflavonoids and hydroxychalcones could be iden- 
tified by this reaction. Therefore, a method for determining the amount of flavonoids by spectrophotometric method in terms of luteolin with a solution of aluminium chloride was chosen for quantitative determination.
Prospects for further research. According to the results of the studies, it is planned to carry out further screening studies to study the pharmacological activity of liquid extract of black poplar buds.

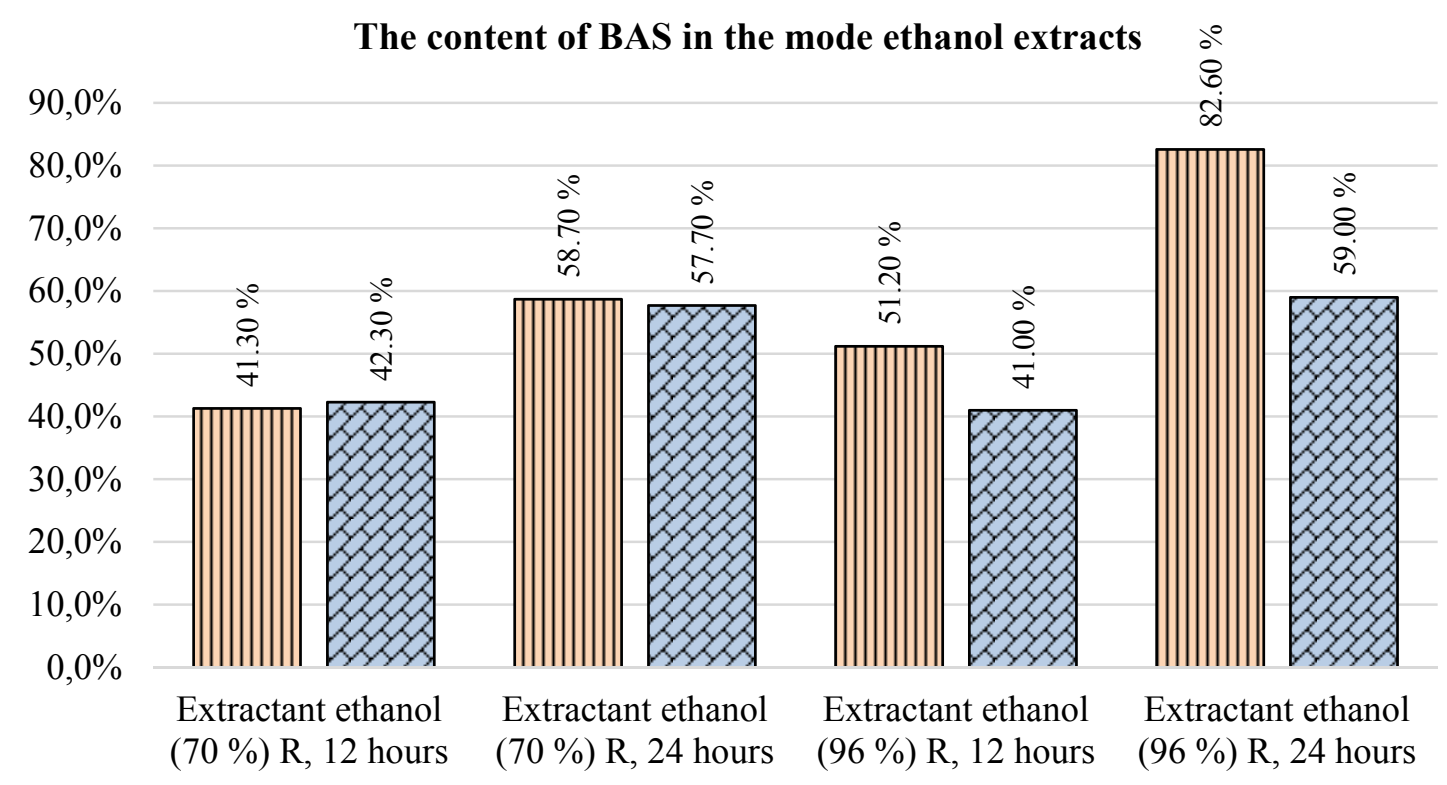

\section{$\square$ Content of flavonoids $\quad$ Content of hydroxycinnamic acid}

Fig. 4. Content of flavonoids and hydroxycinnamic acid derivatives in ethanol extracts based on ethanol (96\%) $R$ and ethanol $(70 \%) R$

\section{Conclusions}

The research on the technology of obtaining liquid extracts of black poplar buds was carried out. The technological parameters of the crushed MPRM black poplar buds were determined, and the extraction parameters were calculated.

The influence of the concentration of the extractant on the qualitative composition of the obtained extract was established. To obtain an extract with a more complete extraction of hydroxycinnamic acids, it is advisable to use ethanol $(70 \%) R$. To obtain an extract with a more complete extraction of flavonoids, it is advisable to use ethanol $(96 \%) R$.

A spectrophotometric quantitative determination of the amount of hydroxycinnamic acid derivatives in terms of coffee acid and the amount of flavonoids in terms of luteolin were performed at all stages of the process of obtaining liquid extracts.

The optimal extraction conditions were selected and the technology for ethanol extracts based on ethanol (96\%) $R$ and ethanol (70\%) $R$, which obtained from the black poplar buds. To increase the absolute content of $\mathrm{BAR}$, it is rational to increase the infusion time to 24 hours. screening.

Ethanol extracts have been tested for further

\section{Conflict of interests}

There are no conflicts of interest regarding this study.

\section{References}

1. Dmytriievskyi, D. I., Ruban, O. A., Khokhlova, L. M. (2016). Suchasnyi stan naukovykh znan spetsialnosti «Farmatsiia». Kharkiv, 98.

2. Shostak, T. A., Kalyniuk, T. H., Gudz, N. I. (2014). Zastosuvannia roslynnykh substantsii v yakosti aktyvnykh farmatsevtychnykh inhrediientiv. Fitoterapiia. Chasopys, 3, 63-65.

3. Harna, S. V., Vladymyrova, I. M., Burd, N. B. (2016). Suchasna fitoterapiia. Kharkiv: Drukarnia Madryd, 580.

4. Dvulit, I. P. (2016). Aktualnist zastosuvannia fitopreparativ yak likuvalno-profilaktychnykh zasobiv u par odontolohichnykh khvorykh. Klinichna stomatolohiia, 2, 8-13.

5. Osokir, abo topolia chorna: opys, likuvalni vlastyvosti i zastosuvannia brunok topoli chornoi. Available at: http://faqukr.ru/zdorov-ja/28327-osokir-abo-topolja-chorna-opis-likuvalni.html

6. Ruban, O. A., Malynovska, S. A., Al-Tovaiti Murad, Mazurets, S. I. (2012). Perspektyvy stvorennia novykh oryhinalnykh preparativ na osnovi substantsii roslynnoho pokhodzhennia. Fitoterapiia. Chasopys, 2, 63-65.

7. Braslavskii, V. B., Kurkin, V. A. (2011). Issledovanie elektronnykh spektrov flavonoidov topolia i propolisa. Medicinskii almanakh, 2 (15), 140-144.

8. Debbache, N., Atmani, D., Atmani, D. (2014). Chemical analysis and biological activities of Populus nigra, flower buds extracts as source of propolis in Algeria. Industrial Crops and Products, 53, 85-92. doi: http://doi.org/10.1016/j.indcrop.2013.12.018 
9. Hage, S., Morlock, G. E. (2017). Bioprofiling of Salicaceae bud extracts through high-performance thin-layer chromatography hyphenated to biochemical, microbiological and chemical detections. Journal of Chromatography A, 1490, 201-211. doi: http://doi.org/10.1016/j.chroma.2017.02.019

10. Benedec, D., Oniga, I., Muresan, B., Mot, A. C., Damian, G., Nistor, A. et. al. (2014). Contrast between Water- and Ethanol-Based Antioxidant Assays: Aspen (Populus tremula) and Black Poplar (Populus nigra) Extracts as a Case Study. Journal of Food Quality, 37 (4), 259-267. doi: http://doi.org/10.1111/jfq.12090

11. Debbache-Benaida, N., Atmani-Kilani, D., Schini-Keirth, V. B., Djebbli, N., Atmani, D. (2013). Pharmacological potential of Populus nigra extract as antioxidant, anti-inflammatory, cardiovascular and hepatoprotective agent. Asian Pacific Journal of Tropical Biomedicine, 3 (9), 697-704. doi: http://doi.org/10.1016/s2221-1691(13)60141-0

12. Dudonné, S., Poupard, P., Coutière, P., Woillez, M., Richard, T., Mérillon, J.-M., Vitrac, X. (2011). Phenolic Composition and Antioxidant Properties of Poplar Bud (Populus nigra) Extract: Individual Antioxidant Contribution of Phenolics and Transcriptional Effect on Skin Aging. Journal of Agricultural and Food Chemistry, 59 (9), $4527-4536$. doi: http://doi.org/10.1021/jf104791t

13. Kuś, P., Jerković, I., Jakovljević, M., Jokić, S. (2018). Extraction of bioactive phenolics from black poplar ( Populus nigra L.) buds by supercritical CO 2 and its optimization by response surface methodology. Journal of Pharmaceutical and Biomedical Analysis, 152, 128-136. doi: http://doi.org/10.1016/j.jpba.2018.01.046

14. Mainar, A. M., Langa, E., Berrueco, B., Maestro, C., Urieta, J. S. (2008). Antioxidant Activity of Supercritical Extracts of Populus Buds. In 11th Eur. Meet. Supercrit. Fluids. New Perspect. Supercrit. Fluids Nanosci. Mater. Process, 2-7.

15. Merghachea, D., Boucherit-Otmania, Z., Hacib, I. E., Merghachec, F. S., Chikhid, I., Boucherita, K. (2016). Antioxidant and antimicrobial activities of algerian populus nigra l. buds extracts. Bioscience \& Engineering: An International Journal, 3 (1-2), 1-8.

16. Soares, J. F., Zabot, G. L., Tres, M. V., Lunelli, F. C., Rodrigues, V. M., Friedrich, M. T. et. al. (2016). Supercritical CO 2 extraction of black poplar ( Populus nigra L.) extract: Experimental data and fitting of kinetic parameters. The Journal of Supercritical Fluids, 117, 270-278. doi: http://doi.org/10.1016/j.supflu.2016.07.005

17. Zhang, J., Cao, X., Ping, S., Wang, K., Shi, J., Zhang, C. et. al. (2015). Comparisons of Ethanol Extracts of Chinese Propolis (Poplar Type) and Poplar Gums Based on the Antioxidant Activities and Molecular Mechanism. Evidence-Based Complementary and Alternative Medicine, 2015, 1-15. doi: http://doi.org/10.1155/2015/307594

18. Derzhavna Farmakopeia Ukrainy. Vol. 1 (2015). Kharkiv: Derzhavne pidpryiemstvo «Ukrainskyi naukovyi farmakopeinyi tsentr yakosti likarskykh zasobiv», 1128.

19. Yevsieieva, L. V., Kovpak, L. A., Vyshnevskyi, I. A. (2015). Vyznachennia tekhnolohichnykh pokaznykiv roslynnoi syrovyny brunok topoli chornoi. Upravlinnia yakistiu v farmatsii. Kharkiv: NFaU, 42.

20. Dubashinskaia, N. V., Khishova, O. M., Shimko, O. M. (2007). Kharakteristika sposobov polucheniia ekstraktov i ikh standartizaciia (chast II). Vestnik farmacii, 2 (36), 70-79.

21. Ruban, O. A. (Ed.) (2015). Praktykum z promyslovoi tekhnolohii likarskykh zasobiv dlia studentiv spetsialnosti «Farmatsiia». Kharkiv: NFaU, 374.

Received date 07.01.2020

Accepted date 04.02.2020

Published date 29.02.2020

Anna Bondar, Clinical Research Specialist, Parexel International, Stepana Bandery ave., 9, Kyiv, Ukraine, 04073, E-mail: anna_andronova@ukr.net

Svitlana Gubar, PhD, Department of Pharmaceutical Chemistry, National University of Pharmacy, Pushkinska str., 53, Kharkiv, Ukraine, 61002, E-mail: gubarsn@ukr.net

Nataliia Smielova, Department of Pharmaceutical Chemistry, National University of Pharmacy, Pushkinska str., 53, Kharkiv, Ukraine, 61002, E-mail: Smelova08@gmail.com

Tatyana Shyteyeva, PhD, Department of Quality Management, National University of Pharmacy, Pushkinska str., 53, Kharkiv, Ukraine, 61002, E-mail: shyteyeva@gmail.com

Olena Tkachenko, PhD, Associate Professor, Department of Quality Management, National University of Pharmacy, Pushkinska str., 53, Kharkiv, Ukraine, 61002

E-mail: elenatkachenko@nuph.edu.ua

Liliia Kryvoruchko, Department of Pharmaceutical Chemistry, National University of Pharmacy, Pushkinska str., 53, Kharkiv, Ukraine, 61002

E-mail: liliya.kryvoruchko@gmail.com

Karina Karpenko, Department of Pharmaceutical Chemistry, National University of Pharmacy, Pushkinska str., 53, Kharkiv, Ukraine, 61002, E-mail: mako.karpenko.73@gmail.com

Viktoria Georgiyants, Doctor of Pharmaceutical Sciences, Professor, Department of Pharmaceutical Chemistry, National University of Pharmacy, Pushkinska str., 53, Kharkiv, Ukraine, 61002

E-mail: vgeor@ukr.net 